\title{
Certitudo coram Deo: Reframing a fascinating feature of Dort
}

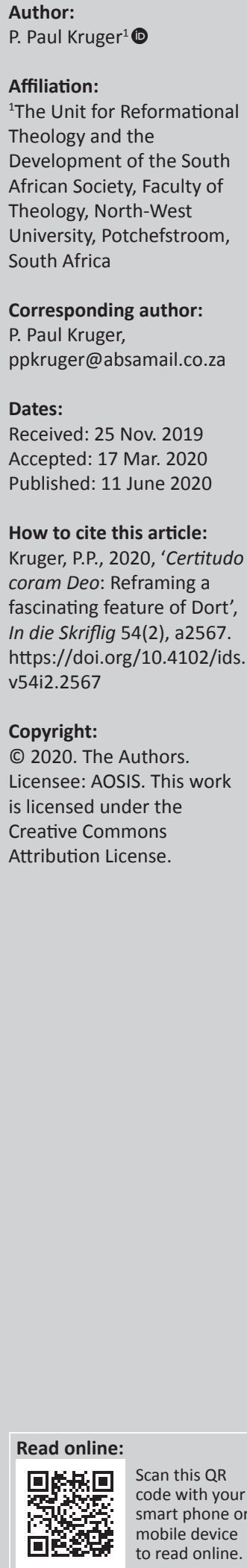

This article combines celebratory contributions to Dort400 and TSP150. It attempts to reframe the fascinating perspective of faith-certainty in Canons of Dordrecht $(5: 5,13)$, in as far as it is linked to a notion of persevering before the undivided face of the living God, alternatively, 'in thy light' (meaning the light 'from thy countenance') - realising that besides the light-side of the fatherly face, there is also has a 'shadow-side'. After explaining the theme in terms of the universal situation of humanity as being coram Deo (before the face of God or in the presence of God), the method of reframing is elucidated as a form of theologia reformanda. The fascinating Dortian feature in question - it is argued - was articulated within historical cadres, aimed at correcting Remonstrant caricaturing of the reformed intentions. The task of reframing this feature, firstly, entails a new 'enframing' thereof within a contemporary late-modern paradigm, captioned under the bird's eye view analogy of a 'Holy Saturday situation'. Aspects of this enframing are indicated as a 'logic of embrace', a stress on the paradoxical 'nevertheless' structure of faith-certainty and a retrieval of the comforting insight that believers participate in Christ's own faith. Secondly, Luther's and Calvin's dramatic expository improvising of Jacob's faith struggle at Jabbok, as he encountered the hidden and revealed face of God, is made transparent. It seems to be an example from an earlier scene in God's great Kingdom drama to be re-improvised in a 21st-century framework.

Keywords: Dordt; Coram Deo; Faith certainty; Reframing; Holy Saturday-age; Archimedian point; God's hiddenness; Calvin; Luther; Faith-play.

\section{Introduction}

\section{Theme}

The theme of this discourse is based on the fourth centenary of the great Synod of Dordrecht (1618-1619) and simultaneously by the hundred and fiftieth anniversary of the Theological School Potchefstroom (TSP). By focussing on a limited - but in our estimation, an extremely relevant and precious perspective in the documents of the Dortian ${ }^{1}$ Synod, we, first of all, seek to express our thankfulness for and indebtedness to that great 'ecumenical' meeting that was convened to resolve the 'most serious religio-political crisis' in Dutch history (Gregory 2012:275). Doubtlessly, it had and has a considerable influence on reformed thinking and living in the world at large and, decidedly, also in South Africa, even unto this day.

This specific feature ${ }^{2}$ seems to be fascinating in three regards. Firstly, it resonates with the contemporary trend to re-emphasise the role of right-brain thinking over against the traditional Western dominance of left-brain reasoning (cf. Armstrong 2019:8-9). Secondly, it is fascinating to note that - in spite of an emerging paradigm-shift away from the Reformation-beginnings - this Dortian rendering is reminiscent of the 'great dramatic form', prevalent in Calvin; moreover, it seems 'so much in the spirit and according to the taste of Calvin that it could have been from himself' (Rijnsdorp 1951:36). ${ }^{3}$ Thirdly, however, a more pregnant facet makes it particularly 'fascinating' (fascinans). It specifically recalls Dort's linking of perseverance in faith-certainty to the 'face of God' (Dei facies) or the 'fatherly aspect of God's countenance' (paternus Dei vultus). The 'captivating attraction' inherent in the concept of fascination no doubt also pertains to the 'shadow-side' (cf. Peels 2003:3) of God's face. Fascinans thus stands in 'contrast-harmony' with tremendum [trembling] (cf. Otto 1936:42-52). 'Contemplating' this face is 'to the godly dearer than life [contemplatio piis vita

\footnotetext{
1.The abbreviations 'Dort' and 'Dortian' follow a well-established American usage (cf. Gunn 2015:8). The name Canons of Dordrecht is
} further on abbreviated as ' $C D$ '.

2.The word 'feature' in the subtheme refers to 'a part (although small) that arrests attention' (cf. eds. Fowler \& Fowler 1958:434)

3.Translations from non-English sources are from the author's hand, except when otherwise indicated. 
dulcior], the withdrawing thereof more bitter than death [subductio morte acerbior]' (Canons of Dordrecht 5:5, 13; cf. Beeke \& Ferguson 2002:122, 123, for the English translation; cf. Bakhuizen Van den Brink 1976:266-267, 270-271, for the original Latin and Dutch text). Although the phrase coram Deo does not - in a 'technical' sense - occur in Dort, it is employed in this article as a gathering up of the abovementioned nuances.

The theme we are broaching in this contribution ineluctably also impinges on the famous and inspiring motto, so wellknown during the past 150 years of the TSP's existence: In thy light. According to Ridderbos (1962:388; author's emphasis), this momentous phrase from Psalms 36:10 means: 'standing in the light of God's face' (cf. also Ps 4: 7 for the petition: 'let the light of your face shine upon us, O Lord'). Sublimely, the significance of this maxim is expressed by a famous German reformed theologian. He intimates that, in this context, God himself is praised as: 'Living Fountain'... (Ps 36:10; 49:20). This fountain 'illuminates the whole creation, in order that we, in his light, might discern what the things, and who we, in truth are' (Moltmann 1991:295). Augustine profoundly expresses our present linguistic inadequacy to articulate the mystery of the fountain that is also the light. He sees Christ as the light and the fountain (Augustine 2007):

That which is the Fountain the same is Light ... for It remains not in one name ... Here sometimes, light is in one place, a fountain in another. For sometimes fountains run even in darkness; and sometimes in the desert you suffer the sun, findest no fountain ... there (in the hereafter) you shall not be wearied, for there is a fountain; there you shall not be darkened, for there is light. (p. 168)

Especially at celebrations like these and in raising a theme like the present one, we should be alerted by nobody less than Bavinck (1968:40) against traits of 'sectarianism' that might arise amongst certain descendants of the Reformation - triumphantly proclaiming our 'own circle', or only our church or only our confession as 'exclusively in possession of the truth'. We, for example, cannot agree with a statement in the Potchefstroom-based journal, Woord en Daad of 15 October 1963: Die Calvinisme is nie ' $n$ soort Christendom nie, dit is die suiwer eenvoudige Bybelse Christendom [Calvinism is not a kind of Christianity, it is the pure, simple biblical Christianity] (cf. Steyn 1998:975, for this quotation; author's emphasis).

\section{Humanity's coram situation}

The term face, implied in coram, suggests an 'ambivalent' reality, 'the looking out which has the character of an active looking at, includes the passive moment of being looked at' (Ebeling 1965:222; author's italics; cf. Scruton 2012:73-111; cf. also 1 Cor 13:13 - knowing fully face to face as being known fully; and 1 Cor 8:3). The significance for Luther of coram Deo has been made abundantly clear in the brilliant doctoral thesis of Bakker (1956: passim). Calvin introduces the dynamic coram

4.In his recent magnum opus on the African Church Father's ethics, Van Wyk (2018:53-54) reminded us: 'through his whole career Augustine incessantly pointed to the total incomprehensibility of God' - an example that should especially be to the total incomprehensibility of God' - an example that should especially be heeded by theologians,
Croasmun 2019:135).
Deo keynote in the very first sentences of the Institutes, where the Reformer contracts 'nearly the sum of all wisdom' in the face-to-face-knowledge of God and humanity, therein also including the whole of creation (Calvin 1962a:37; cf. Seung 2015:1; also Dowey 1965:21, on Calvin's reference to knowledge of ourselves as 'single category' encompassing also the rest of creation). The correlative event of the 'everactive' triune God accompanying us might even be likened to a covenantal face-to-face 'drama of living' (Ford 2014:1, 49) with its penultimate 'scenes' today being enacted in the eschatological, unfinished passage towards the recapitulation (Greek: anakephalosis) or gathering up in Christ of all things (cf. Eph 1:10; cf. Harnack 1961:242-243, for a summary of the 'pregnant fashion' in which Irenaeus of Lyon during the 2nd century developed this thought; cf. also Girard 1997:140, on the idea of transitus [passing through life], which is patterned on incarnation through death to resurrection as the 'fundamental structure of Western art and Western experience'; cf. further McGrath 2017:200, on Dante's Divine Comedy as the pre-eminent imagining of Western man's journey through life; cf. also Calvin 1972:131, on the theatrical allusion embedded in the phrase 'this passing age' of 1 Cor $7: 31)^{5}$

\section{Coram Deo as a 'performed' Archimedian point?}

Aligned with the broader situation of humanity coram Deo, we surmise that the present attempt at reframing a specific Christian perspective might benefit the urgent task of renewing a general 'Archimedian point' (cf. Arendt 1998:257267, on the historical 'discovery of the Archimedian Point'). To this end, we consider a point coram Deo. It denotes 'a temporary place that is again and again given to a human being through the Word and the involvement of God' (De Knijff 1988:57). Furthermore, in our 'thin' world, rampant with meaninglessness, many people feel a deep 'hunger of being part of some dramatic purpose bigger than they are' (Moreland 2007:27; author's emphasis; cf. also Critchley 2019:8, on dramatic sensibility as avoiding 'stupefaction'; cf. also Hauerwas 2013:3). Therefore, our theological preference is 'to be performative' (Ward 2016:140). This also applies to the current reconfiguration of a certitude that could withstand the cultural and scientific 'shifting sands' of history. For thinkers poised on such an Archimedian point it can be true that (Shakespeare cited in ed. Hodek 1987):

...[I]magination bodies forth

The forms of things unknown. (p. 154; [author's added emphasis])

\section{Reframing as a form of theologia reformanda}

The method of 'reframing', as employed in this quest, seeks to continue the 'workings of confessional theology' in 'another register' (Caputo 2013a:61; [author's added emphasis]).

5.According to an incisive analysis by Neuser (2004:28: author's emphasis), Calvin's entrée-move denotes a 'well defined doctrinal structure ... Calvin reflects on God and man in terms of a relationship, in which man is always addressed personally' (cf. also Horton 2014:48 who echoes an insight that Calvin's architecture of his Institutes is oriented to Acts 17 and Romans 1-3: proceeding from the widest circle [entrancing is oriented to Acts 17 and Romans 1-3: proceeding from the widest circle [entrancing
through the coram Deo perspective of 'double wisdom'] to the innermost core of piety, namely, 'Christ as he is clothed in the gospel'). 
As used here, reframing represents a nuanced form of ecclesia reformata semper reformanda (Cilliers 2010:87). It thus reaffirms the five solas of the Reformation, trusting that through God's grace their truth can in our times still engender the dynamic power, beautifully sensed in the following quotation (Vanhoozer 2016):

The solas are the permanent Copernican revolution at the heart of the Reformation, a synopsis of the story that 'turned the world upside down' (Ac 17:6), namely the proclamation of the exclusive lordship of Christ, the crucified king. (p. 28)

Reframing thus intends a 'theological reconfiguration of the existing', as it draws on 'the old to say and do the new by means of juxtaposition' (Cilliers 2010:78; [author's added emphasis]). According to Hayden (2013):

Reframing ... is not a static endeavor [sic] with a fixed end ... (it) leads to new understanding which stirs up new reframing, which leads to new understanding, which leads to reframing, and so on ... [it] remains open to the inbreaking of the Holy Spirit and one another ... expanding the frames through which we interpret the (we may add: 'also confessional') narrative ... (pp. 1-2; [author's added emphasis])

\section{Outline}

The rest of this article deals with, firstly, the (above elucidated) fascinating Dort-feature in its own Contra-Remonstrant framework; secondly, the certitudo coram Deo feature in a possible reconfigured late-modern-reformational 'enframing'; thirdly, an exemplary form of the reframed certitudo coram Deo as resonating Luther's and Calvin's metaphoric use of the father's playfulness in their interpretations of Jacob's faithstruggle at the Jabbok: finally, a brief conclusion.

\section{Dort's 'coram Deo-allusion' in a contra-framework}

The costly 'coram Deo-allusion' (cf. our 'Introduction') of the contra-Remonstrants at the Synod of Dordrecht must clearly be understood in a contra-framework. All their affirmations were made in the context of countering and refuting the Remonstrants' distorted rendering of their convictions. ${ }^{6}$ One Remonstrant caricature concerning the confession of the perseverantia sanctorum was the following: 'that the doctrine of the certainty of perseverance from its own character and nature is a cause of indolence ... (and makes it) praiseworthy to doubt' (cf. CD: Reiectio Errorum 5:6). Viewing the contraRemonstrants' affirmations on the fatherly face in this context, the relevant statements (cf. CD 5:5, 13) might be summarised as follows: an elect person can lose his or her feeling of grace for a time (sensum gratiae ad tempus amittunt), if and when they should abuse God's fatherly kindness thus grievously offending God and incurring a deadly guilt (reatum mortis). In such instances, the elect deviate from God's ordained ways

6.According to Berkouwer (1949:37), the contra-Remonstrants (like the Remonstrants) also argued within the 'dilemma deterministic-indeterministic'; they failed to notice also argued within the 'dilemma deterministic-indeterministic'; they failed to notice 'that faith was not to be subsumed under either of these two'. Nevertheless, the
biblical truth in their contra-Remonstrance, also on issues pertaining to perseverantia, clearly and convincingly carried the day - until today. (viae ordinatae) and experience the turned away face of the father - a taste 'more bitter than death'. By returning into the right way of serious repentance, their assurance of persevering (including their faith-certainty) returns, and - thus walking in the ordained ways - they again experience the fatherly face shining on them in grace, a taste 'sweeter than life' (see also under the section 'Theme' above).

\section{Faith-certainty coram Deo in a contemporary 'enframing' Enframed in an 'Easter Saturday' world}

Contemporary 'enframing' of faith-certainty coram Deo (in its Dortian sense) should make explicit that this accent has 'shifted' into an alternative, new contextual reality (cf. Zizek 2014:33; he uses the neology: to 'enframe'). The contemporary contextual reality into which certitudo coram Deo (in its Dortian form) is understood to have shifted differs from its original context, namely, confessing biblical truth over against caricatures thereof (cf. above). Obviously, to give even a broad overview of, at least, the contemporary cultural and religious framework would vastly exceed the limits and available capability of this inquiry. For the present purpose, it might suffice to underscore the description of contemporary cultural environment as 'an Easter Saturday culture'. This depiction by Lewis (2003:331), within his overall 'theology of Holy Saturday', seems to be a felicitous and profound capturing of what the late-modern paradigm-shift (cf. Caputo 2013b:236, on this 'immensely fertile' concept) primarily entails. ${ }^{7}$ Lewis (2003:412) described the original 'Holy Saturday' in revelation-history - the day between Good Friday and Easter Sunday - as a 'painful pause, empty of hope and filled instead with death and grief, with memories of failure and betrayal, of abandonment and anguish'. With good reason, he hears echoes of this mood in the 'disillusionment, discord and displacement' of our eclipsing 'Western civilisation'. He adds that technology has become a 'demonic monster', accompanied inter alia, by the 'slow insane agonies of planetary self-strangulation' (Lewis 2003:339). Amid the 'kaleidoscope of perspectives' (Lewis 2003:341) ${ }^{8}$ on the contemporary world that might suggest a Good Friday reminiscence, Lewis convincingly sends up flares of a hope, which powerfully impact on the last part of our investigation. His quest for a renewed (dramatic)narrative-rendering of the gospel (cf. Lewis 2003:24-28), in that it includes a promising continuity with the Reformation and Reformed theology (cf. Lewis 2003:474, for the relevant bibliographical references).

\footnotetext{
7.Phenomena like post-colonialism and multi-centricity (cf. Küng 1995:773-775) as well as decolonialism (cf. Ward 2017:576-578) might also specifically be included under this paradigm. Relevant for our investigation, Küng (1991:125-126) also gave prominence to a certain continuity of the 'same religion in different paradigms'.

8. Of course, a veritable plethora of analyses can be marshaled to support, corroborate, update or criticize Lewis' findings. A few random examples are Kennedy (2006:2038), Zizek (2010:vii-xv), Zizek (2017:passim), but especially 225-282, on the 'populist temptation'; Kearney (2011:3-16), on the anatheistic 'drama of decision' Welker (2012:39-47), on the present-day 'Christophobic seeking of God'; Robinson (2015:104), on people who religiously identify themselves as 'nones' but who did (2015:104), on people who religiously identify themselves as 'nones' but who did
not have a chance 'even to reject the beautiful, generous heritage' of the not have a chance 'even to reject the beautiful, generous heritage' of the
Reformation;.cf. Moltmann (2015:1-20); also Volf \& Croasmun (2019:35-59), on our theological crisis situation.
} 


\section{Enframed in the 'logic of embrace'}

A contemporary relational framework - versus a largely substantialist understanding of faith in modern Christian theology - can be enriched by the re-emphasis on a metaphor like 'the divine embrace' (cf. Webber 2006:12). It was Pope Francis (2016:1, referring to the 'Parable of the Merciful Father') who recently also spoke movingly of a 'logic of embrace': 'the embrace and the kiss of his (the prodigal son's) father makes him understand that he was always considered a son, in spite of everything' The embrace of faith is the obverse side of the Father's throwing his arms around us in deep compassion (cf. Webber 2006:145-196). We embrace the triune God in faith coram Deo, as he gives himself to us in Christ through the Holy Spirit who witnesses to him together with (cum) and through (per) the biblical word (cf. Berkouwer 1966:74). ${ }^{9}$ Graphically, Torrance (1996:57) described this unfathomable event: 'we are lifted up by "the everlasting arms"' as the Father embraces us by grace through the Son and in the Spirit. In the 'same act by putting (his) arms around (us)', he draws us to himself, in order that we might put our arms of faith around him. 'Faith embraces Jesus Christ with all his merits. It makes Him our own and seeks for nothing else than Him' (Belgic Confession: Art 22). Indeed (Webber 2006):

Lord Jesus, you stretched out your arms of love on the hard wood of the cross that everyone might come within the reach of your saving embrace. (p. 11)

\section{Enframed in a paradoxical 'nevertheless'}

For our vision of reframing, it is most timely that the ground-breaking work (at least for South Africa) of the well-known theologian Durand (2018: passim) on 'faith and doubt' and their 'continual dynamic tension' was published recently. With urgency, he rightly contends that 'to believe and to keep on believing does not speak for itself' (Durand 2018:209). To many 'fundamentalists', this realisation is so 'deeply unsettling' (McGrath 2017:95) that they require clear propositions guarantying indubitable foundational security as in 'a direct copy of Newtonian science' (Cunningham 2010:296).

Smith (1982; cf. Calvin 1962a:484, Inst 3.2.17, Smith 1982:20) rightly saw 'many of us' reflecting the 'paradoxes in Calvin's thought concerning unbelief and its position in the believer's life':

When we say that faith must be certain and secure, we certainly speak not of an assurance which is never affected by doubt, nor a security which anxiety never assails, we rather maintain that believers have a perpetual struggle with their own distrust (diffidentia) and are thus far from thinking that their consciences possess a placid quiet, uninterrupted by perturbation. (p. 23)

9 An allusion to the dramatic character of this correlative action comes from Billings (2009:435; author's emphasis): 'By participation in Christ th com faith, believs (2009:435; author's emphasis): "By participation in Christ through faith, believers enter into a Trinitarian drama...' where the two hands of the Father [the Word and the Spirit;] (cf. Irenaeus' famous terminology) act together in the 'encounter' of believers with the 'gracious Father'.
Wiir sollen oder können nicht gewiss werden [we shall or cannot become certain], Luther confessed (Bakker 1993:40). That paradoxical cry of faith: 'Lord, I believe, help thou mine unbelief' (Mk 9 verse 24) permanently characterises our faith. A perfect removal of unbelief can never occur in a true faith; as even the most mature believers can never deny 'the imperfection of their faith' (Calvin 1962b:496; Inst 4.14.7; cf. also Wallace 1997:131).

\section{Enframed in the power of 'Christ's own faith'}

Connecting to a theological insight of recent years, the significance of Christ's own faith for the event of faith-certainty coram Deo must be profiled. In fact, this insight adds a decisive dimension to our investigation. The phrase (or a variant form) the 'faith of Jesus Christ' (hé pistis tou [Iésou] Christou) appears seven times in Pauline letters (cf. Gorman 2001:110; Leithart 2016:154-158). Our weak faith exists in communion with Christ's faith as man and - even more - our faith participates in the 'wonderful exchange' [mirifica commutatio] that Christ enacts with us and we with him (Torrance 1996; further, see Jüngel 1988:62-87 on the 'happy exchange' in Luther):

$[O]$ ur response in faith and obedience is a response to the Response already made for us by Christ to the Father's holy love, a response we are summoned to make in union with Christ. (p. 43)

In the light of a text like Roman 3:26b (the one who is out of the 'faith of Jesus' [ton ek pisteos Iésou] is justified), it can be established that we share, participate in or live out of the faith of Jesus (cf. Gorman 2001:139-140). The promises of the Deus promittens are embodied in Christ as God's 'Yes', and in the embodied faithfulness of his human life and death our 'Amen' is spoken and shared with us through the Holy Spirit's 'sealing'(cf. Sauter 1996:150). Convincingly, Theron (2011:52-53) concluded in this regard that 'Christ's faith becomes our faith'. In the same way that we participate in Christ's death and so on, we also participate in his faithfulness to God (cf. Phlp 3:8), Christ believes in our place. Through our faith, we are incorporated or grafted into Christ, thus also into his faith (cf. Heidelberg Catechism 7:20; with the texts). Like a father's unfailing grip encloses his child's feeble and failing grip as they walk through a raging river, Christ's unfailing faith enfolds our faith on 'our uncertain way of faith-certainty' before the face of God (cf. Torrance 1996:29-38).

\section{A reframed faith certainty coram Deo exemplified in coram Deo ludenti form Coram Deo ludenti}

Calvin's and Luther's remarkable treatment of Jacob's perseverance in faith-certainty coram Deo at the Jabbok-ford (Gn 32; cf. also Ridderbos 1962:255, on those seekers of God's face - Ps 24:6 - who may legitimately be called Jacob) models in an exemplary way what we envisaged with our theme. 
We argue that these Reformers' dramatising move in this biblical scene presents a prefiguration for a legitimate contemporary reframing. ${ }^{10}$ The task of such a 21st century attempt at reframing will be the Spirit-filled improvisation (Volf \& Croasmun 2019:159) of this narratively 'staged' scene by the Reformers. Notably, this 16th century 'scene' itself improvises on the canonical Genesis-scene from an earlier part of God's great Kingdom-drama (cf. Ford 2014:20-23, 62-66; Horton 2011:13-32; Vanhoozer 2014: 63-65, 73-112; Wells 2004:45-70).

Explicitly, Luther (1545:96) used the metaphor of a ludus (play) in his improvisation of the canonical scene featuring Jacob at Jabbok. It is crucial that he employs this 'ludic' imagery in the very scene where he sharply discerns the 'sweetness and bitterness' of the two 'aspects' in which the Father's face appears (cf. Dort's articulation above). Berkouwer (1949:170) seemed hesitant to yield to Luther's use of the word 'play' in this instance (cf. Guite 2007:200, for modernity's 'loss of playfulness'; cf. also Moltmann 2000: 162-163). Yet, Luther's characteristic theme of the hidden and revealed God (cf. Ebeling 1965:259-279; Gerrish 1982:132-142; Van den Brink \& Van der Kooi 2013:162) seems to be particularly hospitable to this 'ludic' metaphor. The 'twosidedness of speech about God (focused on his face) upon which Luther laid such stress' ... (this) 'indivisible presence (revealed in his face) ... human language ... is unable of reflecting', said Sauter (1996:151) with good reason. Luther and Calvin after him, nevertheless, honoured God's playful modes of revealing humanly ineffable things as appropriate 'accommodation' to our weakness. Luther's interest in this kind of dramatic expressivity can scarcely be emphasised stronger than in the following words (Hobson 2009):

Luther's revolt was consciously based in a dramatic, reckless performance of faith ... the point (for him) is not to gaze up at scriptural authority, on its pedestal, but to take it down, open it up, make it live, treat it like a play script to be re-performed ... maybe he is just more alertly human than most of us, ever-conscious of selfhood as a dramatic struggle ... I consider his dramatic, positive voice the greatest product of Christendom, worth a hundred cathedrals. (pp. 83-86; [author's added emphasis])

Furthermore, it was nobody less than Noordmans who could speak of Luther's discovering 'the Divine Comedy of Romans 8: 28-39', an event that the Dutch theologian describes as 'one of the copernican changes, as they occur only in singular moments of history'. He was referring to Luther's totally dramatic overturning of the scholastic view that $\sin$ is to be wiped out in man. Luther's amazing discovery was 'that rather man it is that is to be taken away, while sin remains as a residue' (Luther, as quoted by Noordmans 1979:116).

10.Rembrandt's magnificent canvas in the Berlin Museum (Jacob wrestling with the angel. ca. $1650-1660)$ interprets the dramatic timbre of this scene probably better
than any exegete 'in his scientifically well-documented commentary' can do than any exegete in his scientifically well-documented commentary' can do (Velema 1990:47: cf. Jonker 1989:48). It shows the inexpressible and paradoxical simultaneity of the hidden and shining face of God on a single road of encounterthus reinforcing the main thrust of our present reframing. By means of the 'paradoxical light' (Bloch 1968:938), playing on the Angel's face, the paradox of God's chastisement in his grace-giving is reflected (cf. Ford 1999:195; cf. also the slight tilt of the assailant's face and his wonderful wrestling grip, which simultaneously suggests a Father's tender embrace).

\section{Calvin}

Calvin absorbed in the peculiar parlance of a Frenchman all of the accents attributed to Luther in the previous paragraph. Evidence thereof is provided in 'one of the most powerful and profound things that Calvin ever wrote'. This is how a prominent Calvin-scholar (Parker 1982:148) characterises the Reformer's commentary on the dramatic narrative (Gn 32) of a believer who was still walking 'in the twilight of dawn' (Calvin 1975:201). Yet, precisely in realising this specific stage of revelation history - alternatively framed: 'the third Act of God's kingdom-drama' - the canonical occurrence at Jabbok can become transparent as to how the event of a reframed Dortian faith-certainty occurs in our times also, namely, in the unscripted fifth Act of the Kingdom-play; cf. Bartholomew \& Goheen 2004:197-200). We are indeed 'refiguring the play of genesis (sic), prefiguring the play of eschaton, a game that knows no end-game, no stalemate, whose ultimate move is always still to come' (Kearney 2001:110). We thus absorbed this canonical incident in such a way that it 'now functions as (a) background drama of our life' (Smith 2013:127). On faith's way - where we should expect the unexpected event [eventum] God gives us in Jacob's persona a specimen of the trials through which he visits his children. God shows them in such an exemplary coram Deo event that 'in their temptations it is necessary (necesse) for them to wrestle with God' (Calvin 1975:194-195; cf. Calvin 1863:441-442). He brings them in this 'event of contest' (pugnae eventum) and meets them in 'the person of an antagonist' [agonistae persona - id est: in the clothes or costume of an antagonist] in order 'to test them' [examinet Dominus suos fideles]. In this 'arena', God rouses us in medio conflictu pacem imaginemur (in the midst of the fight to imagine peace) (Calvin 1975:195-196; cf. Calvin 1863:433; cf. also Calvin 1973:651, for an explanation of persona: 'in short, the things which the Scripture calls persons are comparable to clothing'). Noteworthy, 'imagination' (imaginemur) is here given a role in faith-certainty coram Deo (cf. Smith 2013:124-130), as we imagine that our wrestling is actually a form of peace. The most amazing of this Jabbokevent, however, is that God (Calvin 1863; cf. Calvin 1975:196 \& Selderhuis 1995:22-30 on Calvin's way of speaking about God's 'left-hand'):

[B]oth fights against us and for us (ut contra nos et pro nos pugnet)... yea, inasmuch as he supplies us with more strength to resist than he employs in opposing us we may truly and properly say (apposite et proprie dicemus), that he fights against us with his left hand and for us with his right hand (sinistra manu ipsum contra nos luctari, dextra autem pro nobis)...It is true that he remains at perfect unity with himself (apud se integer manet): but the double method in which he deals with us cannot be otherwise expressed (sed aliter exprimi non potest duplex illa ratio qua nobiscum agit...). (pp. 442-443)

In a nutshell: this athletic wrestling-event, as a kind of 'arena'-item, issues in Jacob's 'wonderful method of triumphing' (mirabilia triumphandi ratio), as Calvin (1863:444; cf. Calvin 1975:198) calls it: the gracious God allows 'feeble man' (infirmum homocionem) to prevail over him in his very dark and fearful hiddenness - and thus grants this crippled conqueror the overwhelming joy of faith-certainty in 
persevering coram Deo, as Jacob-Israel moves into the breaking morning of Pniel (the face of God). In addition, Calvin highlights God's commendation of the 'invincible perseverance of Jacob' and deems it 'certain' (certe) for all believers that this is the 'legitimate way' (legitimus modus) to wrestle or contend face to face (certandi) with the hidden God. We must never be wearied down 'till the Lord recedes of his own accord' (donec ultro Dominus recedat).

\section{Luther}

'In point of fact', said Gerrish (1982:141), 'it could be shown that Calvin's thoughts on hiddenness parallel Luther's in their full range'. Luther's Lectures on Genesis (1535-1545) give ample evidence of his nuanced use of the play-metaphor, as he ponders the hiddenness of the revealed God; sometimes, he even structurally looks at patriarchal narratives through the lens of classical theatre (cf. Brown 2017:154). In the case, however, of the Jabbok-event - as in other instances - his cue is the homely playing of a benign father with his children (Luther 1915):

God treats his elected patriarch Jacob, according to his great goodness, very friendly (familiarissime) and exercises (exercet) him as if he plays with him most tenderly (quasi colludens suavissime). But this play is an immense sorrow and very great anxiety of spirit (immensus dolor et summa angustiae animi). Yet, in truth it is a play; as the end of it shows, when he comes to Pniel. Because then it will be manifest that it was mere signs (mera signa) of the most intimate love (familiarissima amor). And he played with him thus, because He wanted to test and strengthen his faith therewith [like a good father]. (pp. 96-97; [author's added emphasis])

\section{Conclusion}

The envisaged reframing of a small but fascinating feature of the Canons of Dort - as it is interpreted within its ContraRemonstrant scopus of confessing and upholding biblical insights over-against Remonstrant caricatures thereof - lead to the following outcome:

Firstly, the precious affirmation of this faith-certainty coram Deo could be 'shifted' into the late modern paradigm-era, which is - grossly simplified - characterised with the catchphrase, 'Holy Saturday analogy'. Secondly, Luther's and Calvin's dramatic expository improvisation of Jacob's faith struggle at Jabbok, highlighting the (fatherly playful) hidden and revealed face of God, could be retrieved. It could serve as a challenging example from an earlier (16th century) improvisatory 'translation' of a canonical scene in God's great Kingdom drama. For its part then again it serves as a 'scene' to be re-improvised within a 21st-century framework; always, however, under the aegis of sola Scriptura. A late-modern paradigm could aptly 'enframe' and possibly reinforce - a contemporary fascination with this Dortian confessional asset; arguably, through aspects like the retrieval of a 'logic of embrace', the paradoxical 'nevertheless' character of faith-certainty and believers' comforting participation in our Lord Jesus Christ's own faith-certainty.

\section{Acknowledgements Competing interests}

The author declares that he has no financial or personal relationships that may have inappropriately influenced him in writing this article.

\section{Author's contributions}

P.P.K. is the sole author of this research article.

\section{Funding information}

This research received no specific grant from any funding agency in the public, commercial or not-for-profit sectors.

\section{Data availability statement}

Data sharing is not applicable to this article, as no new data were created or analysed during this study.

\section{Disclaimer}

The views and opinions expressed in this article are those of the author and do not necessarily reflect the official policy or position of any affiliated agency of the author.

\section{References}

Arendt, H., 1998, The human condition, introduction by M. Canovan, 2nd edn., University of Chicago Press, Chicago, IL.

Armstrong, K., 2019, The lost art of scripture: Rescuing the sacred texts, Bodley Head London.

Augustine, A., 2007, Augustine on the Psalms. Psalm 35-37, viewed 27 February 2020 from https://carm.org/augustine-on-psalms-35-7.

Bakhuizen van den Brink, J.N., 1976, De Nederlandse belijdenisschriften in authentieke teksten met inleiding en tekstvergelijkingen, Bolland, Amsterdam.

Bakker, J.T., 1956, Coram Deo: Bijdrage tot het onderzoek naar de structuur van Luthers theologie, Kok, Kampen.

Bakker, J.T., 1993, 'Berkouwer en Luther', Kabats, het faculteitsblad van de theologische faculteit van de Vrije Universiteit 6(5), 40-41.

Bartholomew, C.G. \& Goheen, M.W., 2004, The drama of scripture: Finding our place in the biblical story, Baker, Grand Rapids, MI.

Bavinck, H., 1968, De katholiciteit van Christendom en kerk, Kok, Kampen.

Beeke, J. \& Ferguson, S.B., 2002, Confessions harmonized, with an annotated bibliography of reformed doctrinal works, 4th edn., Baker, Grand Rapids, MI.

Berkouwer, G.C., 1949, Geloof en volharding, Kok, Kampen.

Berkouwer, G.C., 1966, De Heilige Schrift, Deel 1, Kok, Kampen.

Billings, J.T., 2009, 'John Calvin's soteriology: On the multi-faceted "Sum of the Gospel"', International Journal of Systematic Theology 11(4), 428-447. https:// doi.org/10.1111/j.1468-2400.2009.00470.x

Bloch, E., 1968, Das prinzip hoffnung, Dritter Band, Suhrkamp, Frankfurt am Main.

Brown, C.B., 2017, 'Deus ludens; God at play in Luther's theology', Concordia Theological Quarterly 81(1), 153-170. www.ctsw.net/media/pdfs/BrownDeusLud ensGodatPlayinLuther'stheology.pdf.

Calvin, J., 1863, Johannis Calvini opera quae sunt supersunt Omnia, in E. Cunitz, J.W. Baum \& E.W.U. Reuss (eds.), Corpus reformatorum, pp. 442-443, Schwetschke, Berlin.

Calvin, J., 1962a, Institutes of the Christian religion, part 1, transl. Beveridge, Clarke, London.

Calvin, J., 1962b, Institutes of the Christian religion, par 2, transl. H. Beveridge, Clarke, London.

Calvin, J., 1972, Uitlegging op de eersten en tweeden zendbrief van Paulus aan de Corinthiërs, naar de uitgaven van de oude Hollandsche overzetting van J.D., in de tegenwoordige spelling door A.M. Donner, De Groot, Goudriaan.

Calvin, J., 1973, Sermons on the Epistle to the Ephesians, transl. \& rev. A. Golding, The Banner of Truth Trust, Edinburgh.

Calvin, J., 1975, Genesis, transl. J. King, Banner of Truth, Edinburgh 
Caputo, J.D., 2013a, The insistence of God: A theology of perhaps, Indiana University Press, Bloomington, IN.

Caputo, J.D., 2013b, Truth: Philosophy in transit, Penguin, London.

Cilliers, J.H., 2010, 'Preaching as reframing of perspective', In die Skriflig 44(1), 85-97. https://doi.org/10.4102/ids.v44i1.138

Critchley, S., 2019, Tragedy, the Greeks and us, Profile, London.

Cunningham, C., 2010, Darwin's pious idea: Why the ultra-darwinists and creationists both get it wrong, Eerdmans, Grand Rapids, MI.

De Knijff, H.W., 1988, 'Het "coram deo" als conditie van het menselijk bestaan', in G.W. Neven (ed.), Levenslang wachten op U: Teksten over de Godsvraag in deze tijd, pp. 49-61, Kok, Kampen.

Dowey, E.A. Jr., 1965, The knowledge of God in Calvin's theology, 2nd edn., Columbia University Press, New York, NY.

Durand, J., 2018, In awesome wonder: Faith and doubt - A continual dynamic tension, Biblecor, Wellington.

Ebeling, G., 1965, Luther: Einführung in sein denken, pp. 5-8, Tausend, Mohr, Tübingen.

Ford, D.F., 1999, Self and salvation: Being transformed, Cambridge University Press, Cambridge.

Ford, D.F., 2014, The drama of living: Becoming wise in the Spirit, Canterbury Press, Norwich, London.

Fowler, H.W. \& Fowler, F.G. (eds.), 1958, The concise Oxford dictionary of current English, 4th edn., Clarendon, Oxford.

Gerrish, B.A., 1982, The old Protestantism and the new: Essays in reformation heritage, Clark, London.

Girard, R., 1997, Resurrection from the underground, transl. J.G. Williams (ed.), Crossroad, New York, NY.

Gorman, M.J., 2001, Cruciformity: Paul's narrative spirituality of the cross, Eerdans, Grand Rapids, MI.

Gregory, B., 2012, The unintended reformation: How a religious revolution secularized society, Belknap Harvard, Cambridge, MA

Guite, M., 2007, 'Our truest poetry is the most feigning ... poetry, playfulness and truth', in T.A. Hart \& A. Guthrie (eds.), Faithful performances: Enacting Christian tradition, pp. 199-217, Ashgate, Aldershot.

Gunn, G., 2015, 'New Calvinism: A theological evaluation', PhD thesis, Tyndale Theological Seminary, Hurst, TX.

Harnack, A., 1961, History of dogma, vol. 2, transl. N. Buchanan, Dover, New York, NY.

Hauerwas, S., 2013, 'Bonhoeffer: The truthful witness', viewed 14 February 2020 from http://www.homileticsonline.com/subscriber/interviews/hauerwas.asp.

Hayden, J., 2013, 'Reframing the story', viewed 08 February 2019, from https// johnlelandcenter.wordpress.co/2013/01/28/reframing-the-story.

Hobson, T., 2009, Faith, Acumen, Durham.

Hodek, B. (ed.), 1987, 'The complete works of William Shakespeare', Introduction and glossary, Hamlyn, London.

Horton, M., 2011, Christian faith: A systematic theology for pilgrims on the way, Zondervan, Grand Rapids, MI.

Horton, M., 2014, Calvin on the Christian life: Glorifying and enjoying God forever, Crossway, Wheaton, IL.

Jonker, W.D., 1989, Uit vrye guns alleen: Oor uitverkiesing en verbond, N.G. Kerkboekhandel, Pretoria.

Jüngel, E., 1988, The freedom of a Christian: Luther's significance for contemporary theology, transl. R.A. Harrisville, Augsburg, Minneapolis, MN.

Kearney, R., 2001, The God who may be: A hermeneutics of religion, Indiana University Press, Bloomington, IN.

Kearney, R., 2011, Anatheism: Returning to God after God, Columbia University Press, New York, NY.

Kennedy, P., 2006, A modern introduction to theology: New questions for old beliefs, Tauris, London.

Küng, H., 1991, Global responsibility: In search of a new world ethic, transl. J. Bowden Student Christian Movement Press, London.

Küng, H., 1995, Christianity: Is essence and history, transl. J. Bowden, Student Christian Movement Press, London.

Leithart, P., 2016, Delivered from the elements of the world: Atonement, justification, mission, InterVarsity Press, Downer's Grove, IL.

Lewis, A.E., 2003, Between cross and resurrection: A theology of Holy Saturday, Eerdmans, Grand Rapids, MI.

Luther, M., 1915, Kritische Gesamtausgabe, Hsgb. J.F.K. Knaake et al., Böhlhaus, Weimar, viewed 18 November 2019, from https://ia800701,us.archive-org/18/ items/werkektitische44luthoft.

McGrath, A., 2017, The great mystery: Science, God and the quest for meaning, Hodder, London.
Moltmann, J., 1991, Der geist des lebens: Eine ganzheitliche pneumatologie, Kaiser, München.

Moltmann, J., 2000, Experiences in theology: Ways and forms of Christian theology, transl. M. Kohl, Student Christian Movement Press, London.

Moltmann, J., 2015, The living God and the fullness of life, transl. M. Kohl, Westminster John Knox Press, Louisville, KY.

Moreland, J.P., 2007, Kingdom triangle, Zondervan, Grand Rapids, MI.

Neuser, W.H., 2004, 'Calvin's theologisches Leitmotiv “Dei et nostril” in der Institutio von 1536', in V.E. d'Assonville (Jr.) \& E.A. Boer (eds.), Ad fontes: Historiese, teologiese en wetenskaps-filosofiese studies binne reformatoriese kader, Festschrift vir en wetenskaps-filosofiese studies binne reformatoriese kader, Festschrift vir
L. F. Schulze, acta theologica, Supplementum 5, pp. 28-50, Universiteit van die L. F. Schulze, acta theologica,
Oranje Vrystaat, Bloemfontein.

Noordmans, O., 1979, Verzamelde werken, Deel 2, Kok, Kampen.

Otto, R., 1936, Das Heilige, Auflage, Beck, München.

Parker, T.H.L., 1982, 'The shadow and the sketch', in W.H. Neuser, D. Kempff, J.A.B. Holland, C.J. Vos, H.W. Simpson, F.J.M. Potgieter, et al. (eds.), Calvinus reformator: His contribution to theology, church and society, pp. 142-148, Potchefstroom University for Higher Education, Potchefstroom.

Peels, E., 2003, Shadow sides: God in the Old Testament, transl. L. Lalleman, Paternoster, Carlisle.

Pope Francis, 2016, 'The logic of embrace', General audience on St. Peter's Square, 11 May 2016, viewed 26 August 2019, from https://www.ewtu.co.catholicism/ May 2016, viewed 26 August
library/logic-ot-embrace-7351.

Ridderbos, N.H., 1962, De Psalmen, Deel 1, Kok, Kampen.

Rijnsdorp, C., 1951, In drie etappen, Bosch, Baarn.

Robinson, M., 2015, The givenness of things: Essays, Virago, London.

Sauter, G., 1996, Eschatological rationality: Theological issues in focus, Baker, Grand Rapids, MI.

Scruton, R., 2012, The face of God: The Gifford lectures 2010, Bloomsburt, London.

Selderhuis, H.J., 1995, David, Calvijn en ik: Ervaren geloof in de Psalmen, De Vuurbaak, Barneveld.

Seung, G.L., 2015, 'The coram Deo idea in Calvin's theology', viewed 18 November 2019, from https://www-researchgate.net/publication/291447781_The_Coram_ Deo_Idea_in_Calvin's_Theology.

Smith, J.A.K., 2013, Imagining the Kingdom: How worship works, Baker Academic, Grand Rapids, MI.

Smith, J.C., 1982, 'Calvin - Unbelief in the elect', The Evangelical Quarterly 14(1), 14-24. https://biblicalstudies.org.uk/pdf/eq/1982-1_014.pdf.

Steyn, J.C., 1998, Van Wyk Louw: 'n Lewensverhaal, Deel 2, Tafelberg, Cape Town.

Theron, P.F., 2011, Gods geregtigheid en Christus se geloof: Oor die tekens van God se trou, Bybelmedia, Wellington.

Torrance, J.B., 1996, Worship, community and the praise of God, Paternoster, Carlyle.

Van den Brink, G. \& Van der Kooi, C., 2013, Christelijke dogmatiek, 4th edn., Boekencentrum, Zoetermeer.

Vanhoozer, K.J., 2014, Faith speaking understanding; Performing the drama of doctrine, Westminster John Knox Press, Louisville, KY.

Vanhoozer, K.J., 2016, Biblical authority after Babel: Retrieving the Solas in the spirit of mere Protestant Christianity, Brazos, Grand Rapids, MI.

Van Wyk, J.H., 2018, Augustinus: 'n Studie oor die etiek van 'n kerkvader uit Afrika, Sun Press, Stellenbosch.

Velema, W.H., 1990, Nieuw zicht op gereformeerde spiritualiteit, Kok, Kampen.

Volf, M. \& Croasmun, M., 2019, For the life of the world: Theology that makes a difference, Brazos, Grand Rapids, MI.

Wallace, R.S., 1997, Calvin's doctrine of word and sacrament, Wipf, Eugene, OR.

Ward, G., 2016, How the light gets in: Ethical life, part one, Oxford University Press, Oxford.

Ward, G., 2017, 'Decolonizing theology', Stellenbosch Theological Journal 3(2), 561-584. https://doi.org/10.17570/stj.2017.v3n2.a26

Webber, R.E., 2006, The divine embrace: Recovering the passionate spiritual life, Baker, Grand Rapids, MI.

Welker, M., 2012, Gottes Offenbarung: Christologie, 2. Auflage, Neukirchener, Neukirchen-Vluyn.

Wells, S., 2004, Improvisation: The drama of Christian ethics, Society for Promoting Christian Knowledge, London.

Zizek, S., 2010, Living in the end times, Verso, London.

Zizek, S., 2014, Event, Penguin, London.

Zizek, S., 2017, The courage of hopelessness: Chronicles of a year of acting dangerously, Penguin, London. 